\title{
Selling the Bird: Richard Walton Tully's The Bird of Paradise and the Dynamics of Theatrical Commodification
}

\author{
Christopher B. Balme
}

Theatre historians have long been aware of a glaring dichotomy between theatre's cultural impact in a given period and its subsequent canonization in texts and productions. As Laurence Senelick has recently pointed out, the canon of anthologized dramatic texts has little or no room for plays by August von Kotzebue, Voltaire's Mahomet, Aiken's dramatization of Uncle Tom's Cabin, or "perennial crowd pleasers like Charley's Aunt or The Odd Couple."1 This continuing state of selective amnesia cannot be justified simply by reference to criteria of literary quality, as theatre historians have long since liberated themselves from such dictates. Despite acknowledgment of the nonliterary aspects of theatre and the growing body of research into popular theatre and performance, there still remains a lingering suspicion of the longrun hit play and its attendant processes of commodification.

The subject of this essay is a largely forgotten long-run play that had considerable impact on US culture in the first half of the twentieth century. Richard Walton Tully's romantic drama The Bird of Paradise is a perfect example of a serious-minded, commercially successful play that has been erased from our disciplinary memory. Yet it intersects with and reflects many discourses and texts that continue to have influence. The play is set in Hawaii in the early 1890s, the period in which the US annexed the islands and disempowered the native queen and indigenous Hawaiians. The story revolves around a doomed liaison between a young American and a Hawaiian girl. Tully was a collaborator of David Belasco, the author of Madame Butterfly (1900), the inspiration for Puccini's opera, and the play itself was immediately recognized as a Polynesian variation of the Belasco/Puccini melodrama. The Bird of Paradise is explicitly exoticist, implicitly racist, and, perhaps most egregiously, it was a huge commercial success that was performed throughout North America for over a

Christopher B. Balme holds the chair in theatre studies at the University of Amsterdam. Previous positions included professorships at the Universities of Munich and Mainz. Recent publications include a study of postcolonial theatre entitled Decolonizing the Stage with Oxford University Press. Forthcoming is a new book, Dancing in Paradise: Theatricality and Cross-Cultural Performance in the Pacific.

This article is a substantially revised version of a keynote address delivered at the 14th World Congress of IFTR/FIRT at the University of Amsterdam, July 2002.

${ }^{1}$ Laurence Senelick, "Outer Space, Inner Rhythms: The Concurrences of Jules Verne and Jacques Offenbach," Nineteenth Century Theatre and Film 30:1 (Summer 2003): 1-10; here 1. 
decade between 1912 and 1924 and was revived twice on the West End in London. It made both its author and producer a fortune, which they lost and partially regained in the course of one of the most protracted and influential trials on plagiarism in US judicial history; and it played a pivotal role in the popularization of a particular brand of ethnic music and dance, which is known throughout the world and detested wherever lovers of so-called serious music gather. Yet both author and play have practically disappeared without a trace. The text was never published, and only one copy appears to have survived. I shall not be arguing here for the belated commemoration of a forgotten genius or of an overlooked masterpiece. From the point of view of what could be called the modernist canon, both author and play have been probably rightfully consigned to the midden heap of dramatic history. It is not my aim to orchestrate a lament but rather to discuss on the basis of this example how attention to what can be termed the dynamics of commodification may offer new ways of assessing theatre's impact on cultural history.

The play's success poses a number of questions, both general and specific. On a general level, it can be examined as a casebook study of how theatrical commodification functioned in the early twentieth century. This process, however, cannot be understood without examining specific cultural factors. Commodification on any level, I argue, is closely linked to ideological imperatives and discourses that inform it and that it in turn forms. In the case of Tully's play these were a mixture of orientalism, colonialism, and a particularly American variation of the Pacific imaginary, that tropical locus amoenus of free love and carefree existence celebrated by explorers, writers, and painters from Bougainville and Rousseau to Melville and Gauguin. The first section of the article shall be devoted to outlining what can be termed the commodification paradigm in the sense of general principles that could be applied to any commercially successful play. The central sections look specifically at the fortune of Tully's play and its impact on the popularization of Hawaiian performance culture in mainstream America. The final section will discuss the play's disappearance from the theatre historiographical record as symptomatic of a continuing reliance on values still determined by modernist aesthetics.

\section{The Commodification Paradigm}

The rediscovery of the related terms "consumption" and "commodification" by historians and sociologists has resulted in a major branch of interdisciplinary research. Although in public and scholarly consciousness since the beginning of the twentieth century, these words have still an unequivocally pejorative ring. The derogatory usage has a pedigree dating back to Karl Marx's notion of "commodity fetish," Georg Lukács's "reified objects," or more recently Fredric Jameson's diagnosis of late capitalist postmodern culture as being primarily one of commodification. ${ }^{2}$ In the present post-Marxist reformulation they have become terms with which not only to refocus forgotten areas of social history but also to rewrite the narratives of mainstream historiography. ${ }^{3}$ Recent interest in commodities and commodification from a

\footnotetext{
${ }^{2}$ Fredric Jameson, "Postmodernism and Consumer Society," in The Anti-Aesthetic: Essays on Postmodern Culture, ed. Hal Foster (Port Townsend: Bay Press, 1983), 111-25.

${ }^{3}$ Although related, consumption and commodification are by no means synonymous. The former has in fact spawned a branch of post-Marxist historical research sui generis that originated in
} 
cultural rather than from a purely economic perspective can be traced to a collection of essays edited by the anthropologist Arjun Appadurai in 1986, The social life of things: Commodities in cultural perspective. ${ }^{4}$ The editor and authors examine how "things" are sold and traded in a variety of social and cultural settings. They study the underlying social and political mechanisms that regulate taste, trade, and desire, and discuss in particular the ways in which people attach value to objects.

Discussions of commodification intersect in many ways with approaches such as cultural materialism and New Historicism. ${ }^{5}$ Whereas the latter has well-established theoretical and to some extent methodological frameworks in addition to a secure base in art history as well as literary and theatre studies, commodification remains largely a pejorative term and, despite some recent work, is certainly not yet acknowledged as a theoretical approach to theatre history. ${ }^{6}$ With its clear economic connotations commodification can, however, be situated within the broad field of cultural materialist research. Like the latter it is concerned with the material aspects of culture and views the relationship between material factors and cultural phenomena in a much more complex light than does the conventional Marxist notion of a material base and a cultural superstructure.

The commodification paradigm demonstrated below consists of three interlocking perspectives that, for heuristic purposes, can be identified as diachronic, ideological, and aesthetic. Theatrical commodification invariably has a narrative that can be reconstructed. This means that there is a specific chronology pertaining to a play or production and the commodification processes it engenders. Commodification is thus not amorphous and ubiquitous but rather located in defined temporal and spatial coordinates. Consequently, it is possible to observe the passage of theatrical goods across time and space and the changes they undergo. The term "theatrical goods" encompasses any aspect of a production that might enter economic circulation: texts,

Cambridge in the 1980s. By investigating patterns of consumption in Western capitalist countries, these scholars suggested that major social changes usually associated with and explained by the industrial revolution of the nineteenth century were already in place in the eighteenth. See Neil McKendrick, John Brewer, and J. H. Plumb, The Birth of a Consumer Society: The Commercialization of Eighteenth Century England (London: Europa, 1982).

${ }^{4}$ Arjun Appadurai, ed., The social life of things: Commodities in cultural perspective (Cambridge: Cambridge University Press, 1986).

${ }^{5}$ For discussions of the similarities and differences between these two so-called schools, which is more than just a question of the Atlantic divide, see John Brannigan, New Historicism and Cultural Materialism (New York: St. Martin's Press, 1998); and Kiernan Ryan, ed., New Historicism and Cultural Materialism: A Reader (London: Hodder Arnold, 1996). Brannigan focuses particularly on differences in the way power is theorized in the two approaches, accusing the New Historicists of privileging a pessimistic all-pervasive Foucauldian concept of power.

${ }^{6}$ A number of recent studies have engaged explicitly with the question of commodification. They include Erin Mackie's study of eighteenth-century fashion and bourgeois subjectivity, Market à la Mode: Fashion, Commodity, and Gender in The Tatler and The Spectator (Baltimore: Johns Hopkins University Press, 2003). Renaissance studies have made, however, the most significant contributions to the interrelationship between material goods, cultural value, and art. See, for example, Lisa Jardine, Worldly Goods: A New History of the Renaissance (Basingstoke: Macmillan, 1996); Douglas Bruster, Drama and the Market in the Age of Shakespeare (Cambridge: Cambridge University Press, 1993); and Joseph Loewenstein, Ben Jonson and Possessive Authorship (Cambridge: Cambridge University Press, 2002). Broadly speaking, most cultural materialist-inflected scholarship evidences some interest in commodification. 
production concepts, songs, dance routines, costumes, and of course, the performers themselves. It is important to stress that theatrical goods be understood as a wider concept than just the run of the play, although this is invariably the beginning of the commodification process. The many spin-offs resulting from a production may extend many years beyond its own life-cycle. They may also, with the help of other media, reach places where the actual production was never seen.

Commodification assumes that the movement and dissemination of such goods are imbricated in ideological frameworks whereby ideas and beliefs are purveyed under many different guises. Successful commodification presupposes that it taps into some aspect of a society's ideological make-up such as race, gender, class beliefs, etc. Both the narrative movement and the ideological framework of theatrical commodification are useless, however, unless the goods in passage gratify desires aesthetically. These may be as basic as erotic appeal or as "refined" as Kantian beauty. An important aesthetic component of commodification is of course novelty, an interminable search for the new, which suggests a shared common denominator between crass commercialization and modernist formal experimentation.

Broadly speaking, this perspective offers a variety of approaches. It can focus on the interrelations between producers and consumers and the way both are implicated in the cultural and material products and by-products of theatre. Or it can trace the passage of goods, cultural or material, through processes of economic and symbolic transformation. Within this wider economic and cultural field, theatre functions as a nodal point, a highly complex and effective agent of transmission because of its relatively high cultural profile and its multilayered semiotic nature: the multimedium of theatre is not just an aesthetic but also in the broadest sense a cultural processing machine. Seen from this perspective, the notorious problem of theatre's ephemeral nature, its apparent lack of a culturally and historically transcendent work can be readdressed. As a producer of commodities and as part of a larger economic and cultural network of meaning production, the task of the theatre historian is less, in Max Herrmann's famous phrase, to reconstruct "lost achievements until they appear before us with the vividness of a palpable image" than to explore the circulation of cultural goods. ${ }^{7}$ In The Bird of Paradise, I trace how a number of highly valued cultural goods were packaged and processed as marketable commodities: the play itself, of course; Polynesian-or more precisely, Hawaiian-performance culture; and, finally, the Pacific imaginary which the production both drew upon and contributed to.

\section{Rediscovering The Bird of Paradise}

More by chance than good scholarship I came across a newspaper clipping in the British Library that had presumably been filed because it advertised a performance by Sarah Bernhardt in The Grand Opera House at Hamilton, Ontario, in 1917. ${ }^{8}$ On the next night and hence on the same clipping, another production vied for the attention of Hamiltonians, Richard Walton Tully's The Bird of Paradise. The advertisement contained a breakdown of scenes and other information, which suggested an intrigu-

\footnotetext{
${ }^{7}$ My translation. Max Herrmann, Forschungen zur deutschen Theatergeschichte des Mittelalters und der Renaissance (Berlin: Weidmann, 1914), 7.

${ }^{8}$ British Library Mic.F.232.
} 
ing addition to the history of Pacific plays. The fate of Tully and his most famous and successful play can be reconstructed literally by stages as it recedes from public and scholarly memory.

The Cambridge Guide to American Theatre ${ }^{9}$ contains no entry on Tully, although The Bird of Paradise is indexed in the entry on Oliver Morosco, the play's producer, without reference to the author. The recent sourcebook American Playwrights $1880-1945^{10}$ has no entry on Tully either. It is only when we go back into the mid-1980s that we find an entry in The Oxford Companion to American Theatre (1985). ${ }^{11}$ Reference works of this kind provide, by definition, a checklist rather than contextual information. The real problem was that Tully and his play had been emended from the master narratives of American theatre history. In the second volume of The Cambridge History of American Theatre neither play nor author rates even a mention, ${ }^{12}$ despite, as I will show, a prominent position within cultural consciousness for almost two decades. To find a detailed treatment of Tully and some of his works one has to go back to Arthur Hobson Quinn's A History of the American Drama, published in $1945 . .^{13}$ The most detailed discussion of the play and its fortunes is not, however, in the annals of American theatre history but in a now out-of-print account of Hawaii and the Pacific, Anatomy of Paradise, by the social historian and novelist J. C. Furnas, first published in 1937 and revised in $1948 .{ }^{14}$

Who was Richard Walton Tully? Born in Nevada City, Tully was raised in Stockton, California, where his father, a successful banker and mine-owner, was elected mayor of the town for two terms before losing his fortune to a combination of political and natural calamities (antipollution legislation and floods). According to The National Cyclopedia of American Biography, the young Tully started work as a store clerk at four dollars a week before getting a job as an usher at a local theatre. ${ }^{15} \mathrm{He}$ attended local public schools and completed his education at the University of California, Berkeley, with the help of a state scholarship. He first came to notice locally with a farce, James Wobberts, Freshman, written while a student, later renamed A Strenuous Life and produced by Oliver Morosco. Tully attained national prominence in 1906 as the coauthor of the musical drama The Rose of the Rancho, which David Belasco adapted from Tully's play Juanita of San Juan, a study of crosscultural conflict set in the old Mexican missions in California. Although Tully was a prolific writer and the author of a number of stage plays of varying success, none of his work caught the popular

\footnotetext{
${ }^{9}$ Cambridge Guide to American Theatre, ed. Don B. Wilmeth et al. (New York: Cambridge University Press, 1996).

${ }^{10}$ American Playwrights 1880-1945: A Research and Production Sourcebook, ed. William W. Demastes (Westport: Greenwood Press, 1995).

${ }^{11}$ The Oxford Companion to American Theatre, ed. Gerald Bordman (New York: Oxford University Press, 1984); James Hart's The Oxford Companion to American Literature, 5th ed. (New York: Oxford University Press, 1983) has now forgotten Tully, although he did feature in earlier editions.

${ }^{12}$ The Cambridge History of American Theatre 1870-1945, vol. 2, ed. Don Wilmeth and Christopher Bigsby (New York: Cambridge University Press, 1999).

${ }^{13}$ Arthur Hobson Quinn, A History of the American Drama from the Civil War to the Present Day, rev. ed. (New York: Appleton-Century-Crofts, 1945).

${ }^{14}$ J. C. Furnas, Anatomy of Paradise: Hawaii and the Islands of the South Seas, rev. ed. (New York: W. Sloane Associates, 1948); for an account of the play, see 412-19.

${ }^{15}$ The National Cyclopedia of American Biography (New York: James T. White, 1918), 16:94.
} 
imagination quite like the "scientific romance and monograph on Hawaiian life and customs,"16 The Bird of Paradise. In the 1920s he turned to writing for the screen, although with only moderate success. ${ }^{17} \mathrm{He}$ also made a name for himself as a horse breeder. Together with his first wife, the writer Eleanor Gates Tully, he imported and bred the first pedigreed Arabian horses in California. ${ }^{18}$ Tully's career as a writer seems to have ended in the mid-1920s with the plagiarism trial brought against The Bird of Paradise, which will be examined below. Despite ultimate vindication, Tully produced nothing further of note for stage or screen.

The Bird of Paradise is set in the early 1890s, the period in which the US annexed Hawaii and forced the native queen into house arrest until her death. ${ }^{19}$ Its background is eminently political, although the main theme is romantic and exotic, a variation on the popular theme of crosscultural romances and thus heir to a long chain of mainly orientalist western dramas and operas in which indigenous heroines enter into ultimately disastrous liaisons with European men. Within this framework Tully manages to articulate a number of pressing issues affecting indigenous Hawaiians, introducing them both literally and thematically to the New York stage and thus into the center of US media attention. The following plot summary is based roughly on Tully's own précis.

Paul Wilson, a young man fresh from college, comes to Hawaii to work among the lepers of Molokai. The steamer stops at the Puna Coast of the Big Island. There he meets and falls in love with a beautiful Hawaiian girl, Luana, who is a descendant of the Hawaiian king Kamehameha and has been brought up by a Hawaiian priest. They marry, and, instead of proceeding to Molokai, Wilson stays on the island with Luana and her friends and family. There the couple is happy, but the young husband gradually begins to lose his ambition and his self-respect. Other characters interfere in the relationship. They include Captain Hatch, a sugar cane planter; the missionary Sysonby and his wife; Diana, a young American who wants to write a psychological study of Hawaiian magical practices; and Dean, a college-educated beachcomber critical of missionary interference in indigenous culture. Hatch and Sysonby pressure Luana to become queen in Honolulu after the present one has been deposed. More out of love than political conviction, she follows Wilson to Honolulu and into a world of Western conventions, only to find that there she is an incubus upon her husband. The relationship deteriorates. On learning that her people are endangered by volcanic rumblings, she leaves him, returns to the Big Island and, in order to appease the wrath of the goddess Pele, casts herself into the molten maw of a nearby volcano.

${ }^{16} \mathrm{Ibid}$. Other successful plays by Tully with exotic backdrops include Omar, The Tentmaker (1914), set in the Persia of Omar Khayyám, and The Flame (1916), set in Yucatan against the background of the Mexican revolution.

${ }^{17}$ Among other involvements, he wrote and produced the second screen adaptation of Trilby (1923), based on George DuMaurier's famous novel and play.

${ }^{18}$ A detailed account of the Tullys' early married life as writers and horse-breeders near Los Gatos in California can be found in an essay by George Wharton James, "A Happy Couple of Literary Workers: Richard Tully and Eleanor Gates Tully" published in the National Magazine in 1911. (Quoted in George Wharton James, California Scrapbook [Los Angeles: N. A. Kovach, 1945], 115-27.)

${ }^{19}$ I will follow customary usage in Hawaiian studies and use the unmarked form "Hawaii" and "Hawaiian" to refer to the group of islands, while the glottalized form "Hawai'i" designates the island of that name. 
As the plot summary suggests, the play combines popular nineteenth-century South Seas themes-human sacrifice and witchcraft-with contemporary political issues and cultural questions regarding the impact of Western civilization on indigenous cultures. The play reveals detailed knowledge of Hawaiian geography, history, and performance culture; in this complexity it is unique among Western representations of the Pacific of this period. In terms of its scenic devices, the play is an exemplary child of its time with a predilection for hyperrealism. For example, Tully suggests the following effect: "Electric fans to carry the smell of wet kelp out to the audience." ${ }^{20}$ The slavish attention to cultural and scenographic detail is of course typical of fin de siècle theatre and certainly characteristic of the production style of David Belasco and Oliver Morosco, with whom Tully was so closely associated. Nevertheless, the play's place in theatre history is obscure; I will attempt to identify the paradox whereby the reasons for its success were at the same time perhaps the very causes of its disappearance.

\section{The Fortunes of a Theatrical Commodity}

Produced by Oliver Morosco, an erstwhile acrobat and one of the leading theatrical impresarios of the day, The Bird of Paradise premiered 11 September 1911 in Los Angeles at Morosco's Belasco Theater. After a tryout in Rochester in December, it opened in New York City on 7 January 1912 at Daly's Theatre before transferring to Maxine Elliott's on Broadway, where it completed its run. The New York production launched the career of Laurette Taylor (better known today perhaps as the original Amanda Wingfield in The Glass Menagerie), who played Luana. Taylor went on to attain a place in the Broadway pantheon with her role in Peg $\mathrm{O}^{\prime} \mathrm{My}$ Heart, which opened later the same year and was also produced by Morosco. The reviewers were struck by the production's "scenic beauty," the spectacular effects and, as the New York Times critic remarked, "the introduction of the weirdly sensuous music of the island people." It was, however, the final scene- the active volcano "in its suggestion of molten rock, broken by jets of steam and flame"-into which Luana throws herself, that seems to have left the most lasting impression on reviewers, who were generally respectful though not ecstatic. ${ }^{21}$

In his autobiography, Morosco devotes considerable space to describing how "The Bird," as he affectionately called it, came to be one of his biggest successes and a financial cornerstone of his theatrical empire. The play's beginnings were hardly auspicious. In its opening run in Los Angeles at Morosco's stock company Belasco Theater, critics all but ignored it as it ran over five hours on opening night. After ruthlessly cutting Tully's "beautiful verbiage," Morosco rehearsed it down to two hours with the following justification:

"Dick," I swore, "you're a damned fool! Beautiful language never put over a play. Would you rather have an audience bored with your beautiful verbiage or have a real honest-toGod drama? Cut it down to meat, man! That will keep your audience on the edge of their seats. We're not trying to lull them to sleep." ${ }^{22}$

\footnotetext{
${ }^{20}$ Richard Walton Tully, A Bird of Paradise: An American play in three acts. No place (1911). All quotations are from the typescript held in the Library of Congress. This appears to be the only extant copy. The indefinite article of the title was later changed to The Bird of Paradise.

${ }^{21}$ Anon., "Bird of Paradise has Scenic Beauty," New York Times, 9 January 1912, sec. 8.

${ }^{22}$ Oliver Morosco, The Oracle of Broadway: Written from his own notes and comments by Helen $M$. Morosco and Leonard Paul Dugger (Caldwell: Caxton Printers, 1944), 184
} 
Although it ran a respectable five weeks in Los Angeles after Morosco's surgery, the "honest-to-God drama" was still not the talk of the town and had yet to be marketed successfully in New York. Morosco had more faith in the play's commercial potential than in its literary properties: "I was convinced that The Bird, besides being a work of art, was a money-maker, and I was going to do everything in my power to exploit it for all it was worth." ${ }^{23}$ In order to turn a lame duck into an eponymous bird of paradise, Morosco employed a combination of classical marketing techniques and downright subterfuge. On the eve of the New York premiere he gave, as he put it, "extensive interviews to the newspapers" and then embarked on an intensive advertising campaign. He set up thousands of sheet stands all over the city and lined the roads leading into New York with them as well. ${ }^{24}$ The critics still remained lukewarm, so Morosco resorted to an old trick to generate interest. He doled out orders for free tickets to oversell the production, which produced an overexcited audience and ultimately the desired success. For an impresario like Morosco, who financed his theatrical ventures through stocks and shares, a play was a commodity to be prepared, marketed, and sold for maximum profit. Far from being antonymous spheres, art and capitalism coexisted happily within Morosco's philosophy of theatre as interlocking, mutually conditioning activities. ${ }^{25}$

The Bird ran a modest but respectable 112 performances at Maxine Elliot's before embarking on extended tours of North America and many productions at local stock theatres. Although its impact on Broadway was considerable, the play's long-term effect was generated by the multitude of stock company productions that the original spawned. The play was seen throughout the US and Canada over a period of twelve years. A special feature of this play was the personal control that Tully exerted. By the mid-1920s he had personally supervised around thirty separate productions.

Due to the outbreak of World War I, The Bird did not transfer to the London West End until 1919, where it was produced by Sir Alfred Butt in conjunction with Tully. A leading producer, Butt had acquired the rights in 1912 but, as the London Times explained, "preferred to keep it back rather than produce it during the abnormal conditions created by the war." ${ }^{\prime 26}$ Although the London production, which opened at the Lyric 11 September 1919, was entirely recast and redesigned, Tully as usual supervised it and, as he had in North America, organized the importation of Hawaiian musicians. The London version outperformed the New York original, closing on 7 June 1920 after 310 performances. It enjoyed a brief revival in 1922, when it ran for another two months.

Attracted no doubt by the "peerless play"'s commercial success and Morosco's relentless publicity machine, a young California schoolteacher by the name of Grace Altman Fendler filed a lawsuit in 1912 claiming that Tully had plagiarized a play of hers entitled In Hawaii, a version of which she had submitted to Morosco in 1911. For

\footnotetext{
${ }^{23}$ Ibid., 186.

${ }^{24}$ Ibid., 187.

${ }^{25}$ This was of course the fundamental principle of American popular theatre, in particular its melodramatic variety, as Dan Gerould has noted: "Intensively competitive and responsive to market conditions. . . American materialism and entrepreneurial capitalism found in melodrama a congenial art." Daniel C. Gerould, introduction to American Melodrama (New York: PAJ Publications, 1983), 9.

${ }^{26}$ Times, 21 August 1919.
} 
reasons that are still unclear, the case was not heard until twelve years later in 1924 . Fendler was able to prove her case; the court granted an injunction and ordered an accounting of the defendants' profits. A judgment was awarded to the plaintiff for more than $\$ 780,000$, a not unsubstantial sum and an indication of the play's commercial success. Even toward the autumn of its theatrical life, the play was estimated to be grossing about $\$ 100,000$ a year. ${ }^{27}$ The Appellate Division of the Supreme Court upheld the judgement unanimously, thus precluding the possibility of immediate appeal. This ruling forced The Bird off the road for good. It was not until an eminent New York lawyer, Charles H. Tuttle, found a loophole in the law that Morosco and Tully were able to justify an appeal. ${ }^{28}$ The final ruling by the New York Court of Appeals, passed in 1930, reversed the previous decision and required Fendler to pay back the damages awarded plus all costs. The ruling itself became an important precedent in US copyright law and is still cited today in plagiarism cases.

The decisive argument overturning the original decision was that Tully's original scenario antedated the submission of Fendler's manuscript. While he could certainly have theoretically plagiarized the latter's script for details, the original concept was definitely his own. In his close reading of the two versions, the judge set out a legal principle that had a far-reaching effect on US copyright law: "[T]here may be literary property in a particular combination of ideas or in the form in which ideas are embodied. There can be none in the ideas." Over and beyond the legal question, he also provided some insight into contemporary attitudes regarding such subject matter. He noted:

In spite of the entire dissimilarity of the two plays in theme and story there are many similarities in detail. Perhaps this is inevitable in two plays about Hawaii. The very name Hawaii seems to suggest to Americans the hula dance and the sport of swimming; flowers and sunshine and music. It suggests too the dread disease of leprosy. ${ }^{29}$

This may have appeared obvious to an American judge in 1930. It was, however, by no means such an automatic association in 1912. That Americans inevitably associated the name Hawaii with hula and music in 1930 was in fact in no small degree due to the play itself and its success.

\section{Ideological Imperatives}

Successful theatrical commodification depends on products resonating with existing ideological structures, whether affirmatively or negatively. US imperial ambitions, on the one hand, and race debates, on the other, form the ideological framework underpinning the play's success. Its depiction of native Hawaiians is suspended in an unusual tension between sympathy and antipathy. Tully is a clear proponent of the "salvage paradigm," to use James Clifford's term, whereby anthropological, or in this case, theatrical representation may serve to preserve what is ultimately seen as a

\footnotetext{
${ }^{27}$ On the eve of the London production, the Times reported that during the previous season (1918$1919)$, "it brought in receipts of over $£ 40,000$," which converts to approximately $\$ 100,000$ at the exchange rate of the time. Ibid.

${ }^{28}$ See Furnas, Anatomy of Paradise, 416.

${ }^{29}$ Fendler vs. Morosco, Opinion of Court of Appeals of New York, 18 March 1930, 16. Source: http:/ / web.lexis-nexis.com/universe/document. Last visited 6 April 2002.
} 
doomed culture. ${ }^{30}$ Indigenous Hawaiians are represented as being in a transitional phase, caught up in various stages of maladjustment to Western culture. The opening scenes highlight such dissonances acoustically by a "quartet of male voices" singing a Hawaiian song to a European melody, and visually by the disparate costumes worn by two girls; Makia, "a convert," appears in the full-length Mother Hubbard dress, while Liliha, "a Hula dancer," cavorts in a skirt of coconut leaves, "the old-fashioned dress of the Hawaiians." 31

The play is an amalgam of old and new thematic concerns. Typical of the old themes is the criticism leveled at the missionary Sysonby. From the outset of missionary activities in the early nineteenth century, travelers and writers had censured missionary interference in and repression of indigenous cultures in the Pacific. ${ }^{32}$ The selfrighteous Sysonby is thus a familiar caricature, albeit one founded on a century's experience in the Hawaiian islands and elsewhere in the Pacific. His reaction to native customs-whether material in the form of grass-skirts, or performative, as expressed in the hula that is danced in act 1 (fig.1) — is for an early-twentieth-century audience a predictable one:

sYsONBY: My dear children! My dear children! (Increased trepidation) I am pained to find you dancing thus.... Young ladies, dancing of any kind is exceedingly immoral and especially when it is of a nature that makes it allied to vice, superstition and idolatry. ${ }^{33}$

The play engages directly with the coup d'état of 1893 and the ensuing American annexation of the islands in $1898 .^{34}$ The unholy alliance of missionaries (Sysonby) and money (sugarcane planter Hatch) had been much discussed in the debates leading to final annexation. In this regard the play is explicitly political in its exposure of the background to the annexation and articulates unmitigated sympathies for the indigenous perspective-rendered, however, somewhat romantically and improbably via the unlikely story of a Hawaiian princess.

Less obvious today is another thematic complex, eugenics, which would have been immediately accessible to a contemporary audience. The rise of eugenics and the ensuing debates over racial intermarriage, miscegenation, and questions of nonwhite immigration constitute the theme that was perhaps foremost in Tully's mind. In the original scenario he noted:

The disappearance of the so-called inferior races before the advancement of the AngloSaxon race. Degeneracy and death is the penalty that has always been paid by the higher

\footnotetext{
${ }^{30}$ For the term "salvage paradigm," see James Clifford, "Of Other Peoples: Beyond the Salvage Paradigm," The Politics of Representations, ed. Hal Foster (Seattle: Bay Press, 1987), 121-50.

${ }^{31}$ Tully, The Bird of Paradise, 1.

${ }^{32}$ Best known is the criticism leveled by Herman Melville, who wrote in the 1840s in his "novel" Typee that the influence of missionaries in Hawai'i had been effectively to evangelize the natives "into beasts of burden"; Herman Melville, Typee (Harmondsworth: Penguin, 1972), 267.

${ }^{33}$ Tully, The Bird of Paradise, 20.

${ }^{34}$ In 1893 American settlers in connivance with the US government had staged a coup d'état and effectively deposed the ruling Hawaiian queen Liliuokalani. The so-called revolutionary government aggressively petitioned the US government to annex the Hawaiian islands. This was formally done in 1898. For an account of the coup d'état, see Gavin Daws, Shoal of Time: A History of the Hawaiian Islands (Honolulu: University of Hawai'i Press, 1968).
} 


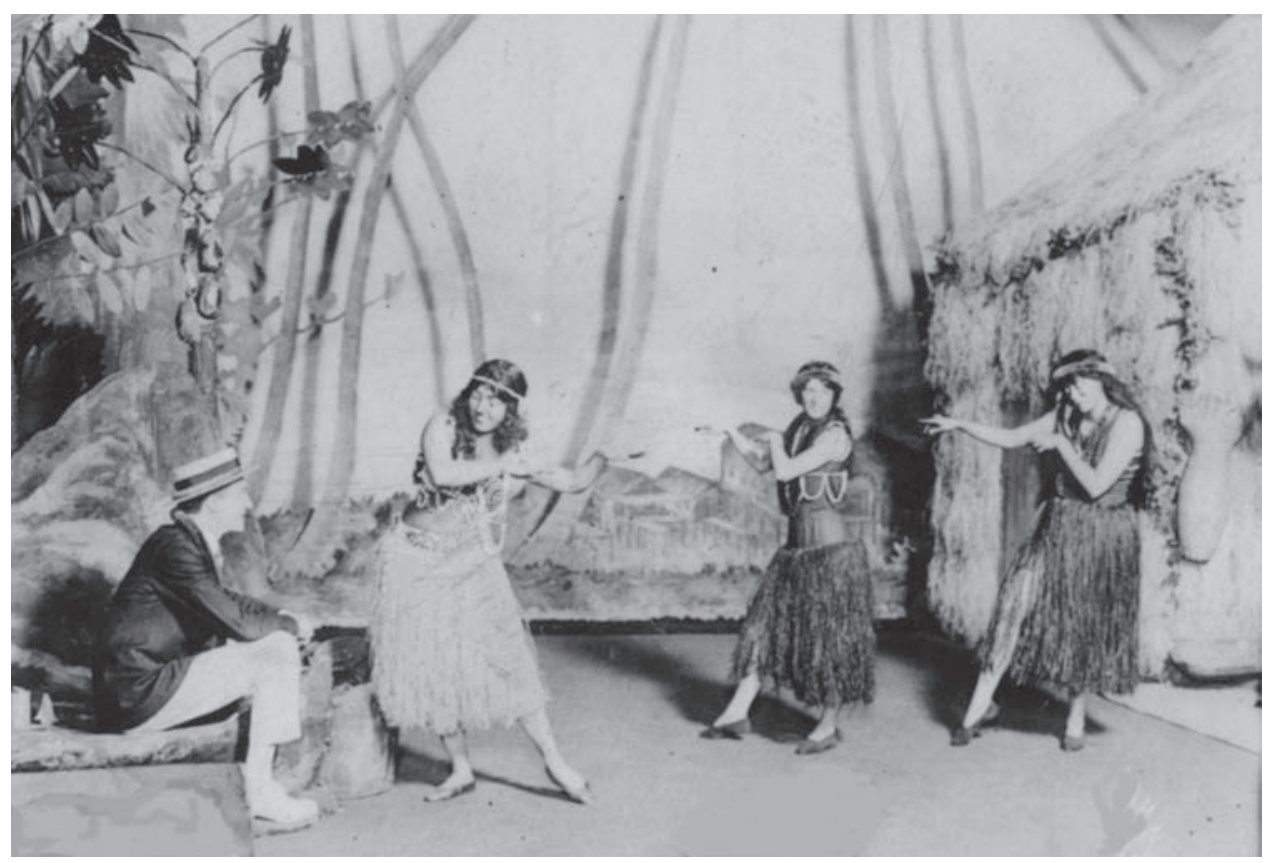

Figure 1. Luana (Laurette Taylor), Liliha (Virginia Reynolds), and Hopoe (Nona Kelly) dance the hula ku'i ("one of the dances of new Hawaii, not the old one") for Paul Wilson (Lewis S. Stone) in act 1 . New York production, Daly's Theatre, 1912. Photo: The New York Public Library.

race that seeks to raise the lower by amalgamating with it. The play thoroughly dramatizes the well-known fact that though we dress, educate and polish the members of a lower race to the superficial religious and social equality with the Caucasian, at heart he is still the fetish-worshipping savage who will become atavistic in every moment of stress. The play is only a tragedy in one sense-that is for the girl who represents the weaker race and the man who mates with her. Hope and salvation are working out for the dissolute beachcomber who climbs from degradation to the highest honor among men through his having kept himself racially pure and his mating with the clear-eyed intelligent girl of his own kind..$^{35}$

In the light of such statements, it is perhaps fortunate that this play has disappeared from our disciplinary records. Yet to dismiss it as an exercise in dramatized eugenics, although ideologically justifiable, would be to bypass its popularity and place in theatrical and cultural history. ${ }^{36}$ From the perspective of its author it was a serious play, an attempt to explore the dynamics and perils of crosscultural encounter, the major theme of his oeuvre. Julian Johnston, the play's first reviewer in the Los Angeles

${ }^{35}$ Cited in Fendler vs. Morosco, Opinion of Court of Appeals of New York, 18 March 1930, 13, n. 32.

${ }^{36} \mathrm{I}$ do not want to argue that Tully was an active advocate of eugenics. His anxiety regarding racial "dilution" with its attendant enervation of "the Anglo-Saxon race" constitutes part of a wider set of beliefs that fed into the "science" of eugenics. In his recent study of eugenics, War against the Weak: Eugenics and America's Plan to Create a Master Race (New York: Four Walls Eight Windows, 2003), Edwin Black demonstrates that the program was not just racially motivated but was also directed at "inferior" members of the "superior" race, as the Nazi euthanasia program so lethally demonstrated. 
Times, attested to its "keen philosophic observation" and "literary solidity." 37 Its appeal to contemporary audiences was, however, probably less philosophic than corporeal. Nevertheless, the subject of interracial encounter was clearly one that interested US audiences over and beyond the teachings of eugenics.

Colonial politics and racial exoticism are of course by no means separate spheres but closely intertwined. Nineteenth- and twentieth-century theatre predicated on exotic sexual relationships-the tradition extending from Meyerbeer's L'Africaine through Madama Butterfly and South Pacific — has always had to work through and even against a growing tension between erotic desire on the one hand and anxiety over miscegenation on the other. ${ }^{38}$ Imperial and exotic desire are interlocking determinants of what Jonathan Arac and Harriet Ritvo have defined as the main function of exoticism in the context of nineteenth-century imperial expansion: the transformation of power politics into spectacle. Exoticism is, they argue, "the aestheticizing means by which the pain of that expansion is converted into spectacle, to culture in the service of empire." ${ }^{\prime 39}$ The dynamics of commodification that I now trace are supported by imperial fantasies on the one hand, and a geographical displacement of American race issues on the other. The "failure" of the relationship between a white American man and a young Hawaiian native woman can clearly be read as an admonitory enactment of a local predicament from the safe distance of a Pacific island. Tully's unequivocal support for the indigenous people is predicated on the same ideological coordinates that would later argue for segregation in the Southern states and "separate development" in South Africa.

\section{Theatrical Goods: Steel Strings, Slack Key, and Hula}

Included in the production was purportedly authentic Hawaiian popular and traditional music. "Authentic" meant that the musicians had been imported from Hawaii. Although Laurette Taylor and other New York actresses rendered the hula, real Hawaiians provided the music. A distinct style of guitar-playing, known as slackkey and played on a steel guitar, had been developed in Hawaii. ${ }^{40}$ As only Hawaiians could at this time play in the style, Tully imported a Hawaiian band known as the Hawaiian Quintette, which included the famous steel guitarist Walter Kolomoku (fig. 2). Their performance led them to become so successful in their own right that they recorded the play's incidental music for the Victor phonograph company, a recording that sold well into the 1920 s. $^{41}$

\footnotetext{
${ }^{37}$ Los Angeles Times, 12 September 1911.

${ }^{38}$ See Robert J. C. Young, Colonial Desire: Hybridity in Theory, Culture and Race (London: Routledge, 1995).

${ }^{39}$ Jonathan Arac and Harriet Ritvo, eds., introduction to The Macropolitics of Nineteenth-Century Literature: Nationalism, Exoticism, Imperialism (Philadelphia: University of Pennsylvania Press, 1991), 3; cited in Graham Huggan, The Postcolonial Exotic: Marketing the Margins (London: Routledge, 2001), 14.

${ }^{40}$ Hawaiian slack key guitar $(k i$ ho' $a l u)$ is a unique acoustic guitar tradition developed in the islands. In this tradition, the strings (or keys) are adjusted (or slacked) to produce many different tunings and the characteristic lingering sound.

${ }^{41}$ See Tim Gracyk and Frank Hoffmann, Popular American Recording Pioneers 1895-1925 (New York: The Haworth Press, 2000), 117-19. Also significant, according to the authors, was the appearance in 1915 of Keoki Awai's Royal Hawaiian Quartette at the Panama-Pacific International Exhibition in San Francisco. In late 1915 Victor began issuing Hawaiian discs on a monthly basis; 118.
} 


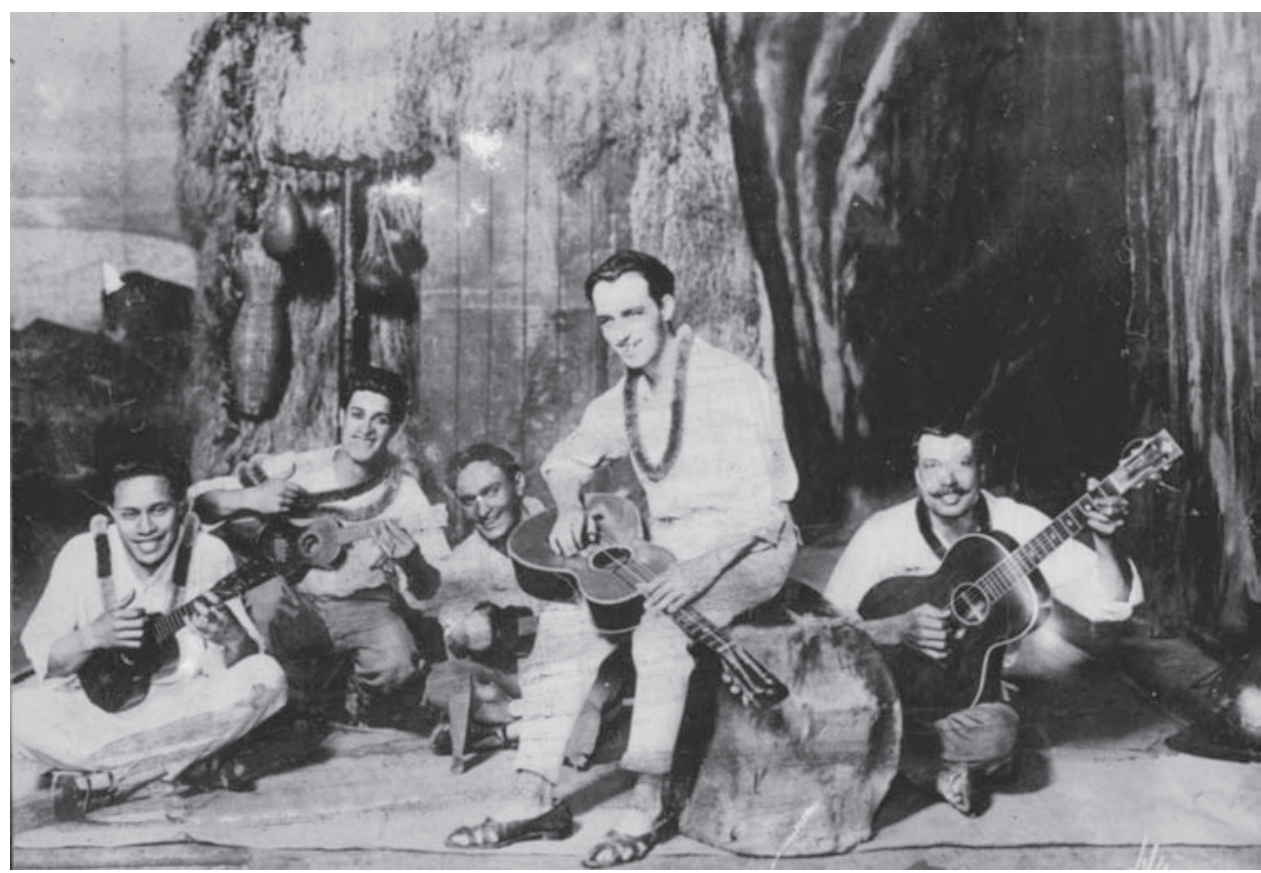

Figure 2. The Hawaiian Quintette on the set of the original New York production, 1912.

Photo: The New York Public Library.

In 1916 the Edison Phonograph Monthly published an article entitled "Hawaiian Music Universally Popular," in which the sudden success and breakthrough of Hawaiian music was traced back to the interest generated by the play and the recording.

Two years ago what did the public know about Hawaiian Music, Ukuleles, Hula Hula Dances? Since then Hawaiian music and American versions of it have taken the United States by storm. ... For years travelers who returned from Hawaii brought stories of the strange and beautiful music that the natives played on their Ukuleles, but it was not until Tully's opera "The Bird of Paradise" was produced that musicians gave any serious attention to the instrument and its music. This opera, with its wonderful setting of exotic music, however, brought the Hawaiian instrument into prominence. . . . A few months ago its music was translated to the American public through the medium of HawaiianAmerican ragtime and since then it has sprung into universal popularity. ${ }^{42}$

The appearance of Hawaiian popular music via Tully's play and its foregrounding of Hawaiian musicians resulted in a rage for the new music and its icon, the "Honolulu girl." Irving Berlin produced a ragtime parody of the play, and the Hawaiian craze engendered by it, in songs such as "My Bird of Paradise," issued in 1915. By the end of World War I, Hawaiian recordings, especially acoustic steel guitar and vocal performances, were the biggest selling records in the US music market.

\footnotetext{
42 "Hawaiian Music Universally Popular," The Edison Phonograph Monthly 14, no. 9 (September 1916):
} 3. 
Apart from recordings, sheet music of the songs was also published and satisfied a huge demand for merchandizing and spin-off products. The sheet music was invariably illustrated (fig. 3) with the images of Luana in her native costume. The music itself, scored for piano and the moderately trained voice of the home parlor, provided the most accessible way for consumers to process the Hawaiian experience they had had at the theatre. This device is of course so familiar today from the cinema with its commodification chains of DVDs, videos, toys, and hamburgers that we tend to forget its origins in the theatre. ${ }^{43}$

While Tully's original play only had provision for Hawaiian songs motivated by plausible occasions for singing (but does not contain exact titles or lyrics), subsequent developments of the production included more and more numbers, pushing the play closer to opera or musical. One of the most popular numbers was the song "One, two, three, four." Composed by the Hawaiians Jack Alau and S. Kalama in 1906, it has been described by admirers of popular music as arguably "the worst song ever written." 44

Down by the stream where I first met Rebecca

Down by the stream where the sun loves to shine

Bright hued the garlands I wove for Rebecca

Bright were her eyes as they gazed into mine

One, two, three, four, some times I wish there were more

Ein, zwei, drei, vier, I love the one that's near

Yet, nee, sam, see, so says the heathen Chinee.

Fair girls bereft, there will get left, one, two, and three ... .5

Owing to the growing prominence of Hawaiian music and popular songs, it is perhaps not surprising that The Bird was revived-and quickly flopped-as a musical in 1930 under the title Luana. The original play was also presented within the Federal Theatre Project at its birthplace, the Belasco Theater, in Los Angeles in the late 1930s. Its poster, which features a swimsuit-clad maiden rather than the more traditional grass skirt, demonstrates that the former was now an integral part of the iconographical repertoire of Hawaii, although such images have nothing to do with the original play. ${ }^{46}$

The images produced on sheet music and posters almost always alluded to the hula. By the time the play was first produced, the hula had become a standard feature of entertainment in the growing tourist trade to Hawaii, although pre-World War I tourism was by no means comparable to the mass industry of the post-World War II period. The version presented to the tourists was a composite of Polynesian dance forms developed in the latter half of the nineteenth century. Despite the increasing prominence of the hula on the Hawaiian islands themselves, there was at the time no real popular conception of the dance on the mainland. This was to change with the impact of the play, and above all its dissemination in stock company productions throughout North America.

\footnotetext{
${ }^{43}$ This aspect of commodification has its roots in nineteenth-century popular theatre. The most successful example was no doubt Uncle Tom's Cabin, which spawned spin-off industries including the play itself, "songs ... Uncle Tom dishes and crockery, restaurants and even a board game." Gerould, ed., American Melodrama, 14.

${ }^{44}$ http:/ / parlorsongs.com/issues/1999-12/dec99feature.asp.

${ }^{45}$ Lyrics: S. Kalama, Music: Jack Alau. Sheet Music: In Songs of Hawaii (Miller Music Corp., 1950).

${ }^{46}$ See Library of Congress POS - WPA - CA .01 .B549, no. 1.
} 


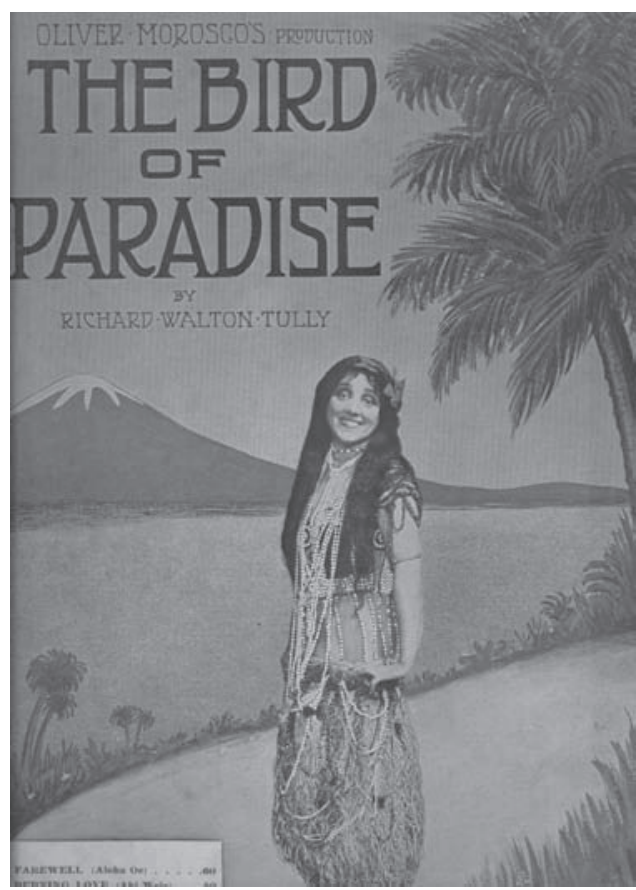

Figure 3. Sheet music cover featuring Laurette Taylor. A photograph of Taylor has been superimposed on the background picture. The song is "Mai Poina Oe" (Forget me not), composed by W. A. Aeko with English lyrics by Arthur Denvir. John Franklin Music Co., 1912.

Photo: Private Collection.

Onstage Laurette Taylor and her many successors in the role of Luana danced the hula. ${ }^{47}$ According to her daughter, Taylor received instruction from one of the members of the Hawaiian Quintette, S. M. Kaiawae, a "fat little Hawaiian . . . who moved like a fat little wave. ... When she could balance a gourd full of water on the back of each hand and undulate her hips without spilling a drop, he pronounced her proficient." ${ }^{48}$ She even learned some words of Hawaiian-certainly enough to sing the songs-and anecdotal legend has it that the intensive rehearsal sessions in her tenement flat she shared with her mother generated so much adverse interest from the neighbors that she was threatened with eviction. Tully was also not amused, objecting not only to Taylor's Irish accent but also to her-in his eyes-less than authentic hula dancing. ${ }^{49} \mathrm{He}$ advised to "merely 'indicate' the hula with a few motions" that he demonstrated in rehearsal..$^{50}$ Authentic or not, Taylor's rendition of the hula took New York by storm, and Kaiawae was able to cash in on the craze by providing instruction to enthused epigones.

\footnotetext{
${ }^{47}$ Marguerite Courteney, Laurette (New York: Atheneum, 1966), 113.

${ }^{48}$ Ibid., 113-14.

${ }^{49}$ In her determined pursuit of cultural authenticity, she managed to acquire something like a Hawaiian accent which, to the ears of some reviewers, was detrimental to her diction.

${ }^{50}$ Ibid., 115. Tully's "expertise" in matters of Hawaiian culture had been acquired in the course of two visits to the islands, one of which was financed by an advance from Morosco on the strength of the original scenario.
} 
Of her numerous successors in the role of Luana, the most illustrious was probably Lenore Ulric, who, like Taylor, went on to have a career as a Broadway and occasional Hollywood actress. Ulric had in fact played alongside Taylor in the original production and took over the role when Taylor left to perform in Peg $\mathrm{O}^{\prime} \mathrm{My}$ Heart. In terms of fostering hula in American popular culture and dance, Ulric probably played an even more pivotal role than had Taylor. She was a close friend of Gilda Gray of the Ziegfeld Follies whose (in)famous shimmy dance ostensibly had Hawaiian origins. The effect of Ulric's Luana and her hula dancing has been documented by Hawaii's "poet laureate," Don Blanding, who, by his own account, immigrated to Hawaii on his last dollar after seeing her perform Luana in Kansas City in 1916:

A girl danced. With hands and arms undulant as restless waves, her body supple as a swaying vine, her bare feet moving with caressing lightness, she danced against an exotic background of trailing, tangled lianas and tall, sky-rocketing palm trees. ${ }^{51}$

In fact, it was not Ulric but Olin Field who performed in that production; nevertheless, Blanding's error indicates that Ulric had by this time come to be associated with the role more closely than Taylor ever had.

The Bird and hula dancing produced of course the inevitable imitations; this, too, was an essential part of the dynamics of commodification. The first imitation was the musical comedy Tangerine that ran for a year on Broadway from August 1921. Composed by Carle Carlton with lyrics by Howard Johnston, the undemanding script was contributed by Philip Bartholomae and Guy Bolton. Its major drawing card was again hula girls and ukeleles. Of more lasting impact was the "drama of tropic passion" Aloma of the South Seas. Written by John B. Hymer and Leroy Clemens, it had an inauspicious run of 66 performances in New York in 1925 before embarking on extended tours and stock productions in the hinterlands. It spawned a novel and at least three cinematic versions; the most notorious was the 1926 silent version featuring Gilda Gray doing the hula. To promote the film, Gray toured with a group of musicians, The Royal Samoans, and performed her "Polynesian dance" before showings. The play's publicity material marketed unashamedly the erotic side of the South Seas that in The Bird was more implicit than explicit. Partially and totally unclad darkhaired maidens pose blatantly (fig. 4), while the advertising copy oscillates between voyeurism and racism in its representation of the indigenous body:

Aloma of the South Seas: An enchanting and picturesque drama of the tropics, with weird and entrancing music, bewitching and shapely native maidens with hibiscus in their black tresses, and stalwart brown-skinned Apollo-like men who though natives have all the chivalry and noble pride of their race. It is the story of the primitive passion and coquetry of a native girl, and the gallantry of a white man. ${ }^{52}$

When we consider that the first reviewer of The Bird charged its author with writing a "philosophic play," then the processes of theatrical commodification represented by

\footnotetext{
${ }^{51}$ Don Blanding, Hula Moons (New York: Dodd, Mead \& Co., 1930), 2-13; cited in Furnas, Anatomy of Paradise, 414. After immigrating to Hawai'i under the impact of Luana's hula, Blanding (1894-1957) established himself as a novelist, journalist, and illustrator on the islands and remained there until his death.

${ }^{52}$ Publicity material, Laurence Senelick Collection. My thanks to Laurence Senelick for drawing my attention to this material and for granting permission to reproduce it.
} 


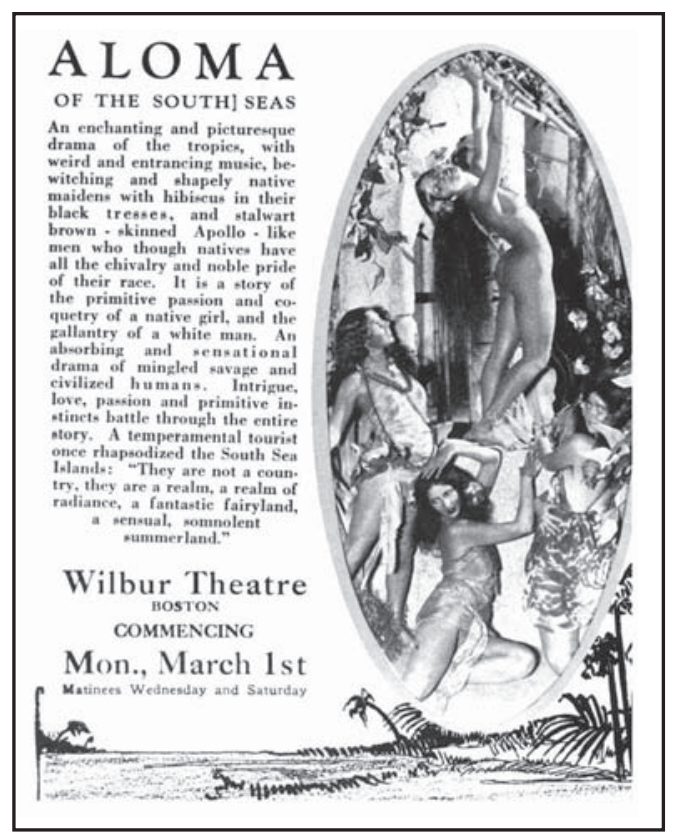

Figure 4. Aloma of the South Seas. Publicity Material, ca. 1925.

Photo: Laurence Senelick Collection of Theatrical Imagery.

Aloma of the South Seas indicate that they do not necessarily result in an increase in moral complexity. On the contrary, the commodity "South Seas," as designed by the The Bird-with its combination of exotic music and dance, potential miscegenation, and downright sex appeal-had become a set of predictable elements.

By 1930 we can say that the commodity The Bird of Paradise had run its course. Its cultural, mimetic, and financial capital seems to have been expended, milked of any last drops of novelty and selling power. This cultural exhaustion is best demonstrated by the fact that in 1932 it was made into a moderately successful film, directed by King Vidor and starring Dolores del Rio, whose only links with the play are the title and the heroine's self-immolation in a volcano. ${ }^{53}$

\section{Regimes of Value}

An extinct volcano is perhaps an apt metaphor for the mighty property that The Bird of Paradise had once been. As we have seen, the original production received a mixed critical reception at best. The reactions of reviewers are of only secondary importance, however, when it comes to elucidating the relative success of a play such as The Bird of Paradise, which could not be said to have taken Broadway by storm but rather accrued

\footnotetext{
${ }^{53}$ The 1932 version was an RKO Radio production, produced by David O. Selznick. The rights to the stage play had been purchased by his predecessor at RKO, W. LeBaron. It was filmed again in 1952, directed by Delmer Daves, and featuring Louis Jourdan as a French sailor who falls in love with the sister (Debra Paget) of his Polynesian friend (Jeff Chandler). The only similarity with the original is again the volcanic sacrifice.
} 
impact through extended tours and a long-term existence in the cultural imaginary. "Relative success" is the key term here because of the play's paradoxical presence and absence: its inescapable presence, as has been shown, and its subsequent disappearance from our cultural and disciplinary record. The fact of its disappearance-a convenient one considering its racial politics-should make us question why we cannot find a place for theatre of this kind and importance in our chronologies and narratives. I have argued that a shift of focus away from modernist-driven accounts of aesthetic advancement towards an engagement with theatre's place in a culture of commodification could go some way to rectifying the problem. However, to investigate theatre within this paradigm has quite severe consequences. It requires a serious concern with economic and material factors as well as with theatre's imbrication in cultural fields that can only marginally be considered art. A professional engagement with theatre's place in history demands a perspective that can link questions of representation with those of economic and cultural impact, so that the type of theatre represented by The Bird of Paradise is not relegated to a footnote but regains, if not center stage, at least a respectable supporting role, as it did in its time.

In order to explain the disappearance of such works we have to engage with the problem of canonicity and cultural value. Today it is something of a commonplace that literary and theatrical value are not necessarily congruent, a position that was formulated most succinctly by Max Herrmann with his observation that, for the study of theatre history, "the most artless play can be in some circumstances more important than the greatest dramatic masterpiece of world literature." 54 Although Herrmann's position today would probably not be seriously contested by most theatre historians, its consequences have not been followed through in all respects. While literary canon formation and associated questions of ownership such as plagiarism have in recent years begun to be discussed within cultural materialist research, ${ }^{55}$ analogous work has yet to appear for theatre of the early modernist period. Although most theatre historians would agree that literary and theatrical canonicity are not necessarily commensurate, their critical vocabulary is frequently still framed in the traditional pejorative vein, whereby commercially successful drama is reduced to merely another commodity, implying a clear dichotomy between highbrow and lowbrow, art and commerce. Recent discussion in the field of cultural studies has come to question the validity of such distinctions. It is one of the enduring modernist myths that "culture" is in some way outside or independent of the processes of commodification, but in actual fact the imbrication of modernism and the market are manifold, as the cultural theorist John Frow has pointed out. It is therefore necessary, he argues, to find other criteria for distinguishing different forms of aesthetic production and response:

High culture is fully absorbed within commodity production. The relation to the market can therefore not be used as a general principle of differentiation ... nor is it any longer possible to employ the traditional value-laden opposition between the disinterested,

\footnotetext{
${ }^{54}$ Max Herrmann, introduction to Forschungen, 4.

${ }^{55}$ See, for example, John Guillory, Cultural Capital: The Problem of Literary Canon Formation (Chicago: University of Chicago Press, 1993); Laura Rosenthal, Playwrights and Plagiarists in Early Modern England: Gender, Authorship, Literary Property (Ithaca: Cornell University Press, 1996); and Paulina Kewes, Authorship and Appropriation: Writing for the Stage in England 1660-1710 (Oxford: Clarendon Press, 1998).
} 
organic, original, self-governing work of art and the interested, mechanical, formulaic, and commercial mass-cultural text. ${ }^{56}$

If the "relation to the market" or "imbrication in the culture industry" (as Adorno and Horkheimer argued in the Dialectic of Enlightenment ${ }^{57}$ ) is no longer the decisive and distinguishing factor between high and low culture, how can we reconceptualize the different ways audiences/consumers relate to aesthetic products? Without relinquishing entirely the dichotomy between high and popular culture and borrowing from Arjun Appadurai, Frow proposes the concept of "regimes of value" to reformulate the old problem. These he understands as a "semiotic institution generating evaluative regularities under certain conditions of use, and in which particular empirical audiences or communities may be more or less imbricated." 58 As "semiotic institutions," regimes of value are concerned as much with exchanges of symbolic as with actual capital. Following Appadurai's reading of Georg Simmel's central argument in The Philosophy of Money (that economic value is nowhere ever general or immutable, but always determined by "the commensuration of two intensities of demand"), Frow suggests that regimes of value can be used to reevaluate crosscultural exchanges. ${ }^{59}$ Demand is of course prompted by desire, which can be very visceral when we think of the basic needs (food, sex), but can also be determined by more complex cultural regimes of desire in the sphere of consumer or cultural goods (DVD players or theatre productions). Whether high or popular, both regimes, Frow argues, share the same goal of "converting commodities into non-economic values (aesthetic values, which however take on an ethical or experiential form)." ${ }^{60}$ Taking this argument one step further, one could posit that this multifaceted conversion process of turning a commodity (in our case a theatre production) into other forms of cultural value can be an object of investigation sui generis.

That The Bird of Paradise and its author have fallen through the grids, checks, and balances of our disciplinary archives and narratives should cause us to pause and consider to what extent our historiographical master narratives are still ill-equipped to assess such phenomena. The play, it could be argued, provides a textbook example of Appadurai's commensuration of intensities or Frow's conversion processes. The dynamics of commodification that the play's fortune illustrates are not primarily of financial interest-at least not to the theatre historian. Rather, the economic success is an index of deeper-seated cultural questions that must be excavated. These include, as has been demonstrated, America's growing interest and involvement in the Pacific, its own unresolved racial conflicts that could be safely acted out in an exotic clime, and an increased appetite for ethnic music and dance. These potential readings point to the play's imbrication in a variety of cultural, social, and performative discourses. The fact that it has disappeared can only be explained by theatre history's undue reliance on

\footnotetext{
${ }^{56}$ John Frow, Cultural Studies and Cultural Value (Oxford: Clarendon Press, 1995), 23. The art market for modernist painting is the most obvious example, but similar arguments could also be made for certain types of theatre and performance.

${ }^{57}$ Max Horkheimer and Theodor W. Adorno, Dialectic of the Enlightenment, trans. by John Cumming (New York: Herder and Herder, 1972).

${ }^{58}$ Frow, Cultural Studies, 144.

${ }^{59}$ Arjun Appadurai, "Introduction: commodities and the politics of value," in Appadurai, ed., The social life of things, 4 .

${ }^{60}$ Frow, Cultural Studies, 23.
} 
what historians have termed "modernism's master narrative of culture," which means a history of culture focused on "artistic production, individualism, originality, genius, aestheticism, and avant-gardism." ${ }^{61}$ In this narrative, only those works that programmatically defy commodification find a place in the archive.

That theatre historians have internalized modernism's master narrative of aesthetic progress can be demonstrated by the entry on Oliver Morosco, the producer of The Bird of Paradise, in the Cambridge Guide to the Theatre. The authors note that Morosco's own plays were "all undistinguished," and close with the following sentence: "The Morosco Theatre, however, took its place in history in 1920 when Eugene O'Neill's first full-length play, Beyond the Horizon, was presented there as a matinee." ${ }^{62}$ Although hardly a major work, Beyond the Horizon nevertheless ensures Morosco a place in history. A minor work by a modernist master ultimately rescues a key theatre figure of the early-twentieth-century American stage from obscurity. This perspective is a major cause of why and how theatre history forgets. Its frames of reference are still conditioned by a definition of theatrical canonicity in which attention is focused on the aesthetic component defined by the players themselves.

\section{Conclusion}

The Bird is certainly exemplary of what Thomas Mann once called the bad nineteenth century, a concoction of spectacularism, doubtful (from today's perspective) ideology, and, in Theodor W. Adorno's view, execrable music. Yet it also seems to have delighted and enthralled an earlier generation to the measure of many millions of dollars. The Bird was undoubtedly produced and marketed as a commodity. At the same time, it was also conceived and received as a serious piece of theatre, which expressed sympathy with the plight of the indigenous Hawaiians while at the same time resonating with eugenic philosophy, one of the most controversial debates of the last century. Over and beyond its possibly philosophical intent, it became ultimately a kind of theatrical trademark that entered and circulated in a number of cultural systems: judicial, musical, and touristic, to name just a few. It played a crucial role in defining and cementing the Pacific imaginary in the US as a scene of erotic, racial, musical, and performative encounter, a scene that was to be revisited some forty years later by the musical South Pacific that exploited the same cultural and performative equation and produced equal if not greater commercial effects.

At the beginning of the twenty-first century, it would seem that our historiographical regimes of value are changing. A theatre historiography that embraced the modernist narrative of progress and replacement could not remember The Bird, whereas a discipline that has absorbed the many challenges posed by cultural materialist research can embrace the contradictory positions such a work poses. At the very least, an expanded and flexible understanding of commodification as a cultural, aesthetic, as well as a commercial process can go some way to helping us grasp theatre's power in the past.

\footnotetext{
${ }^{61}$ Bermingham and Brewer, eds., introduction to The Consumption of Culture, 3.

${ }^{62}$ Martin Banham, ed., Cambridge Guide to the Theatre, new ed. (Cambridge: Cambridge University Press, 1995), 761.
} 